\title{
Young's modulus estimation techniques for the randomly oriented natural fiber reinforced composites: Finite element analysis and analytical models
}

\section{Gelişigüzel doğal lif takviyeli kompozitlerin elastiklik modülü tahmin yöntemleri: Sonlu elemanlar analizi ve analitik modeller}

\author{
Mehmet Safa BODUR ${ }^{*}$ (iD), Mustafa BAKKAL ${ }^{2}$ i \\ ${ }_{1}^{1}$ Materials Science and Nanotechnology Engineering, Faculty of Engineering, Yeditepe University, Istanbul, Turkey. \\ mehmet.bodur@yeditepe.edu.tr \\ ${ }^{2}$ Mechanical Engineering, Faculty of Mechanical Engineering, Istanbul Technical University, Istanbul, Turkey. \\ bakkalmu@itu.edu.tr
}

\begin{abstract}
In the study, elastic modulus estimation methods of natural fiber reinforced composites considered as alternatives to synthetic fiber reinforced composites have been investigated. Finite element analysis (FEA) and some mathematical models which are used for synthetic fiber reinforced composites were preferred. During the study, randomly oriented cotton fiber reinforced composites at different fiber ratio by volume were investigated and the tensile test results were found experimentally. Experimental data were compared with data obtained using finite element method and current analytical models. Particularly in low fiber reinforced composite samples, the data obtained from the analytical models approximated between 2-4\% of the experimental data. On the other hand, in the analysis by the finite element method, it is observed that the difference with the experimental results is opened as the high deformations are occurred. The most suitable analytical models have been found in the study and have been proposed for such composites. Moreover, the behavior of composites can be simulated by finite element methods and closed results (17-23\%) are revealed in this respect.
\end{abstract}

Keywords: Natural Fibers, Composites, Modelling

\section{$\ddot{0 ̈ z}$}

Çalışmada sentetik lif takviyeli kompozitlere alternatif olarak düsünülen doğal lif takviyeli kompozitlerin elastisite modülü tahmin yöntemleri incelenmiştir. Yöntem olarak sonlu elemanlar analizi ve sentetik lif takviyeli kompozitler için kullanılan matematiksel modellerin uygunlukları araştırılmıştır. Çalışma boyunca ele alınan kompozitlerhacimce farklı oranlarda gelișigüzel pamuk lifi takviyeli olup çekme test sonuçları deneysel olarak bulunmuștur. Deneysel veriler sonlu elemanlar yöntemi ve mevcut analitik modeller kullanılarak elde edilen veriler ile kıyaslanmıștır. Özellikle düșük lif takviyeli kompozit numunelerde analitik modellerden elde edilen veriler deneysel verilere yaklașık olarak \%2-4 arasında yaklașmıștır. Diğer yandan sonlu elemanlar yöntemiyle yapılan analizlerde ise yüksek șekil değiștirme oranlarına doğru gidildikçe deneysel sonuçlarla aradaki farkın açıldığı gözlenmiștir. Calıșma neticesinde en uygunan alitik modeller bulunmuș ve bu tarz kompozitler için önerilmiştir. Ayrıca sonlu elemanlar yöntemiyle kompozitlerin davranışları taklit edilebilmiş ve deneysel değerler ile yakın (\%17-23) sonuçlar ortaya çıkarılmıştır.

Anahtar kelimeler: Doğal lifler, Kompozitler, Modelleme

\section{Introduction}

Estimation methods are used to reduce the cost of composite materials during production and characterization stages and to develop the designs. Despite the complexity of the methods, the three-dimensional (3D) finite element model approach of the unit cell is the most preferred method of predicting elastic modulus or damage analyses of fiber-reinforced composite materials.In the method, the fibers are considered to be orthotropic and the matrix material has isotropic properties in the three-dimensional model. Early examples of this approach have been put forward by studies conducted by Whitcomb [1], Guedes and Kikuchi [2]. The applications of the approach are used in the following studies [3]-[5] to find the thermal expansion coefficients by making use of unit cells with modulus of elasticity and coefficients. In modeling approaches, usually the fiber structure, representative (or self-repetitive) volume element, rarely unit cells (elements) and appropriate boundary conditions can be modeled. Thus, the behavior of the modeled element can be approximated to the behavior of the whole structure [6]. In addition, different approaches have been developed using different Poisson ratios [7]-[9]. On the other hand, it is also possible to make modeling by facilitating the finite element method by means of analysis software designed for this purpose, as it is in a study by Lomov et al. [10].

On the other hand, analytical models are used to predict the mechanical behaviors of composite materials in advance. Existing studies for estimating the elastic modulus values of natural fiber reinforced composites are rare and the feasibility of the preferred models for short fiber reinforced composites and how closely these models can yield results should be determined. Different micro and macro mechanical methods can be used to predict the tensile properties of short fiber reinforced composites.

In order to reach the theoretical strength values of composite materials, it is necessary to know the volume ratios of fiber and matrix, the way of distribution of fibers (directed or random) and their mechanical properties.Modulus of elasticity and tensile strength are considered to be the most important properties of the materials used in engineering problems.

Fiber and matrix material, fiber volume ratio, fiber length and distribution are the most commonly used parameters to theoretically calculate elastic modulus and strength of composites. 
Although there are many methods for estimating modulus of elasticity of composite materials, any existing method can not be used due to the complicated structure of natural fiber reinforced composites. Therefore, it is necessary to find out which method is more suitable by comparing the existing analytical methods. The existing methods for estimating the elastic modulus are generally divided into 2 groups. The first and most important group considers the most basic properties of fiber and matrix materials and fiber matrix mixture states.Mixture model [11], Cox model [12], Halpin-Tsai and Tsai-Pagano mode [13],[14], Nielson model [15], Christensen and Waal model [16],[17], Manera approach model [18], Fiber Density Function Model-Pan model [19], Hirsch model [20] and Shear Lag [12] are the most used models.The other group gives an idea of the modulus of elasticity of the composites taking into account the mutual interactions of the fiber and matrix [21]-[24].

In a study conducted by Ji Zhao Liang and his colleagues in 2011, analytical models that take into account the interfacial strength factor could be used to estimate the strength values of synthetic fiber-reinforced polymer composites [25]. Piggott and his colleagues have focused on models that take into account the fracture-based theories of fibers [26]. Epaarachchi et al., on the other hand, used empirical models to predict the mechanical properties of synthetic fiber/vinyl ester composites with randomly oriented fiber distribution in a study they conducted [27].

Although many studies have been carried out in order to estimate the strength values of synthetic fiber reinforced composites, very rare studies have been carried out on natural fiber reinforced composites.For example, Bigiotti and colleagues used semi-empirical models to estimate the strength values of $20 \%$ linen fiber reinforced polypropylene composites [28]. In another study, elastic modulus values of different natural fiber reinforced composites at 10\%-60\% volumetric ratios were calculated with existing analytical models and compared with experimental data. As a result of the study, Halpin - Tsai model was found to be the closest model to the experimental results [29].

As the studies done in the past are examined, it is seen that models are usually developed and used on synthetic and oriented fiber reinforced composite materials.In this study, the adaptability of the existing models used in the estimation of modulus of elasticity moduli based on elastic deformation region of synthetic fiber reinforced composite materials was investigated. Thus, by comparing the existing methods, the methods which are most suitable according to these composites have been revealed. For this purpose, the most commonly used analytical models and the finite element method were used.

\section{Materials and method}

In the composite structure, low density polyethylene as matrix material and cotton fiber as reinforcement are preferred. Textile waste as a fiber source of cotton was evaluated in a composite structure. $100 \%$ cotton textile wastes (30 Ne (Linear Density-Number English (Ne)) supplied by Zorlu Textile.Low Density Polyethylene (LDPE) polymer matrix used as matrix material was supplied from PETKIM with G03 code. Composite materials have a random cotton fiber content of $6.5 \%, 13 \%$ and $19.6 \%$ by volume, respectively (Composites have designations with respect to cotton fiber content Textile Fiber Reinforced Polymer (T-FRP) $/ 6.5 \%, \quad$ T-FRP $/ 13 \%$ and T-FRP $/ 19.6 \%$ respectively). On the other hand, the maleic anhydride interfacial bonding agent (Fusabond E226) used in fiber/matrix interfacial adhesiondevelopment methods was supplied by DuPont. The main properties of cotton fiber and matrix material are given in Table 1.

Table 1: Properties of matrix and fiber element [30],[31].

\begin{tabular}{ccccc}
\hline Material & $\begin{array}{c}\sigma_{\text {uts }} \\
(\mathrm{MPa})\end{array}$ & $\mathrm{E}(\mathrm{MPa})$ & $\rho\left(\mathrm{g} / \mathrm{cm}^{3}\right)$ & $v$ \\
\hline LDPE & 9.2 & 220 & 0.92 & 0.49 \\
Cotton Fiber & 189.5 & 4700 & 1.53 & 0.33 \\
\hline
\end{tabular}

Figure 1 gives a flow-chart in order to clarify the composite production process. According to the flow chart, after the manufacturing process, composite plates were pressed to maintain constant thickness and flatness. Samples for tensile testing were cut out off from the calibrated plates by using a desktop CNC milling machine. The remaining plates were granulated for the next processing step (reprocessing). The extrusion and granulation processes were repeated three times in order to provide fiber homogeneity.

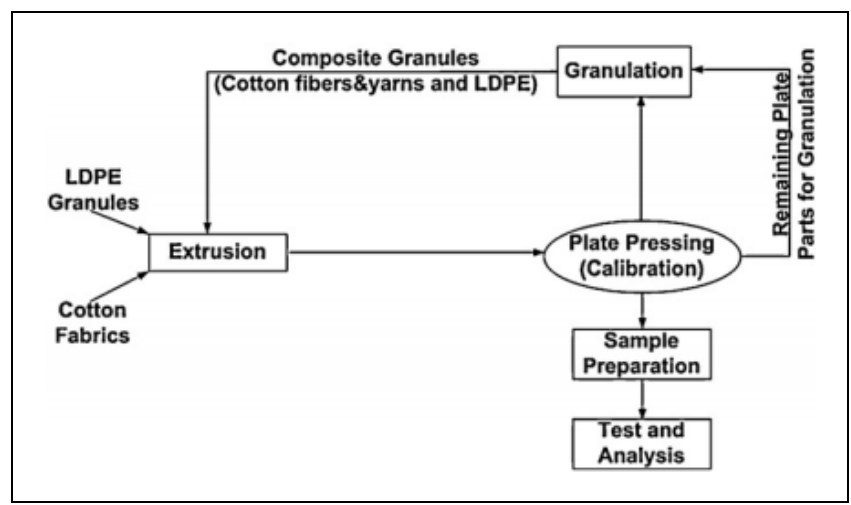

Figure 1: Fabricationandreprocessingflowchart of the sample preparation [32].

Tensile testing was performed in order to determine tensile strength (TS), Young's modulus (YM), failure strain (FS) and wascarried out according to ASTM D638-08: Standard Test Method forTensile Properties of Plastics. Type I specimen dimensions wereused for specimens having a thickness of $7 \mathrm{~mm}$ or less. Static tensiletests were conducted in the laboratory where the temperature wasat $23{ }^{\circ} \mathrm{C}$ and had $50 \%$ relative humidity. The specimens were tested using a shimadzu AG-IS tensile testing machine fitted $50 \mathrm{kN}$ load cell operated at a cross-head spedd of $50 \mathrm{~mm} / \mathrm{mm}$. Optical extensometers followed by two digital cameras were used to measure strains. At least five specimens were tested for each batch with agauge length of $50 \mathrm{~mm}$ and results were averaged arithmetically.strains. At least five specimens were tested for each batch with agauge length of $50 \mathrm{~mm}$ and results were averaged arithmetically. Figure 2 shows the sample for tensile testing.

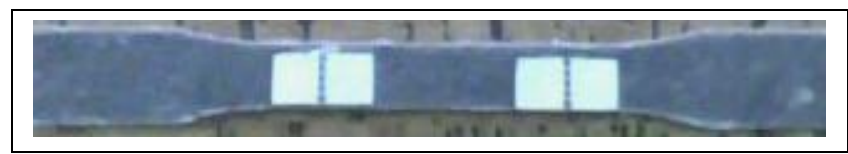

Figure 2: Test sample for tensile test.

The average fiber length of cotton fibers is measured as 1.18-3.67 $\mathrm{mm}$ and the fiber diameter as $0.09 \mathrm{~mm}$. By taking these values into consideration, the theoretical strength properties of composite materials were calculated and 
compared. In Figure 3, experimental tensile test curves of composite specimens are given. Single screw extruder machine with special screw-barrel design is used for the production of composites. Thanks to the special screw-barrel design, textile wastes are prevented from being clogged in the extruder. The polymer granules were mixed with the textile waste according to the desired weight and volume ratios. The granulation process has also been applied to convert the textile waste into cotton fibers to provide a more homogeneous structure.

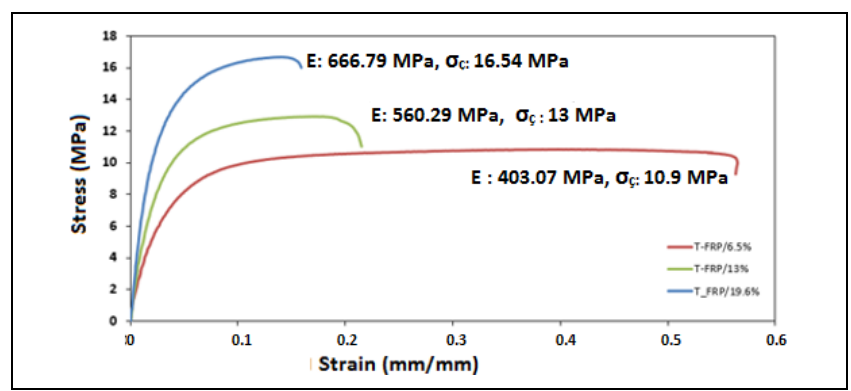

Figure 3: Stress-Strain curves of composite with different fiber ratios.

Analytical models available in literature [33]-[42] chosen for the study are presented as follows.

\section{$2.1 \quad$ Rule of mixtures}

$$
\begin{gathered}
E_{c}=V_{f} V_{f}+\left(1-V_{f}\right) E_{m} \\
E_{c}=\frac{1}{\frac{V_{f}}{E_{f}}+\frac{\left(1-V_{f}\right)}{E_{m}}}
\end{gathered}
$$

Where;

$E_{c}$ : Composite Young's Modulus (Longitidual),

$V_{f}:$ Fiber volumetric ratio,

$E_{f}$ : Fiber Young's Modulus,

$E_{m}:$ Matrix Young's Modulus.

\subsection{Modified rule of mixtures (MRoM)}

$$
E_{c}=\eta V_{f} E_{f}+\left(1-V_{f}\right) E_{m}
$$

Where;

$\eta$ : Constant (0.2 for randomly oriented composies)

\section{$2.3 \quad$ Cox model}

$$
\begin{gathered}
\eta=1-\frac{\tanh \left(\frac{\beta l}{2}\right)}{\left(\frac{\beta l}{2}\right)} \\
\beta=\frac{l}{r} \sqrt{\frac{E_{m}}{E_{f}(1+v) \ln \sqrt{\frac{\pi}{4 V_{f}}}}}
\end{gathered}
$$

Where;

"n" is determined by the formulas and used in MRoM.

$l$ : Fiber length $(\mathrm{mm})$

$r:$ Fiber radius $(\mathrm{mm})$

$\beta$ : Stress concentration ratio for fibers

$v$ : Poisson's ratio for fibers

\subsection{Halpin tsai}

$$
\begin{gathered}
E_{11}=\frac{1+2\left(\frac{l_{f}}{d_{f}}\right) \eta_{L} V_{f}}{1-\eta_{L} V_{f}} E_{m} \\
\eta_{L}=\frac{\left(\frac{E_{f}\left(d_{f}\right)}{E_{m}}\right)-1}{\frac{E_{f}\left(d_{f}\right)}{E_{m}}+2\left(\frac{l_{f}}{d_{f}}\right)}
\end{gathered}
$$

Where;

$E_{11}$ : Longitiduanal Young's Modulus

$\eta_{L}:$ Longitidiunal constant

\subsection{Tsai pagano}

$$
\begin{gathered}
E_{\text {random }}=\frac{3}{8} E_{11}+\frac{5}{8} E_{22} \\
E_{22}=\frac{1+2 \eta_{T} V_{f}}{1-\eta_{T} V_{f}} E_{m} \\
\eta_{T}=\frac{\left(E_{f}\left(d_{f}\right) / E_{m}\right)-1}{\left(E_{f}\left(d_{f}\right) / E_{m}\right)+2}
\end{gathered}
$$

Where;

$E_{\text {ran }}:$ Young's Modulus of Randomly oriented composites $E_{22}:$ Transverse young's modulus $\eta_{T}:$ Transverse constant

\subsection{Nielson}

$$
\begin{gathered}
X_{c}=X_{m}\left(\frac{1+A \eta V_{f}}{1-\eta \psi V_{f}}\right) \\
\psi=1+\left(\frac{1-\emptyset_{\max }}{\emptyset_{\max }^{2}}\right) V_{f} \\
A=K-1=2 l / d \\
K=1+2 l / d \\
\eta=\frac{\frac{E_{f}}{E_{m}}-1}{\frac{E_{f}}{E_{m}}+A}
\end{gathered}
$$

Where;

$\Phi_{\text {max }}:$ Maximum fiber density ratio (0.82)

$l / d:$ Fiber length/diameter

\subsection{Christensen and waal}

$$
E_{3-D}=\frac{c}{6} E_{f}+\left[1+\left(1+v_{m}\right) c\right] E_{m}
$$

Where;

$c$ : Fiber ratio by volume and should be less than 0.2 $v_{m}$ : poisson's ratio for matrix

\subsection{Approximation model by manera}

$$
\bar{E}=V_{f}\left(\frac{16}{45} E_{f}+2 E_{m}\right)+\frac{8}{9} E_{m}
$$




\subsection{Pan's model}

$$
E_{c}^{3 D}=E_{f} \frac{V_{f}}{2 \pi}+E_{m}\left(1-\frac{V_{f}}{2 \pi}\right)
$$

\subsection{Hirch model}

$$
\begin{aligned}
& E_{c}=\alpha\left[V_{f} E_{f}+\left(1-V_{f}\right) E_{m}\right] \\
&+(1-\alpha)\left[\frac{1}{\frac{E_{f}}{E_{m}}+\frac{\left(1-V_{f}\right)}{E_{m}}}\right]
\end{aligned}
$$

Where;

$0<\alpha<1$

\subsection{Shear lag model}

$$
\begin{gathered}
E_{11}=\eta_{l} V_{f} E_{f}+\left(1-V_{f}\right) E_{m} \\
\eta_{l}=1-\frac{\tanh \left(\frac{\beta l}{2}\right)}{\frac{\beta l}{2}} \\
\beta=\left(\frac{H}{\pi r_{f}^{2} E_{f}}\right)^{\frac{1}{2}} \\
H=\frac{2 \pi G_{m}}{\ln \left(\frac{R}{r_{f}}\right)} \\
R=r_{f} \sqrt{\frac{K_{R}}{V_{f}}}
\end{gathered}
$$

Where;

$K_{R}:$ Fiber packing factor [42].

\section{Results and discussion}

Figure 4 shows graphs of variation in modulus of elasticity according to fiber volume ratios and results from analytical models. In general, as expected, the modulus of elasticity of fiber reinforced composite materials in low proportion is empirically and theoretically close to each other.For example, Modified Rule of Mixtures (MRoM) (3.7\%), Halpin-Tsai (2\%), Nielson (4\%), Hirsch (3.8\%) and Shear Lag (2.7\%) models presents the closest possible results for composite material containing 6.5 vol. \% cotton fiber. As the fiber ratio increases, the difference between experimental data and analytical models increases. In composites containing $13 \%$ volumetric fiber, the closest results were obtained by MROM, Halpin-Tsai, Nielson and Hirsch models which has difference about 3.7\%, $3.5 \%, 4.9 \%$ and $0.7 \%$ compared to the experimental data respectively.

As all fiber ratios are taken into consideration, we can see that MRoM and Hirsch models give the closest results to experimental data. In addition, some analytical models exhibit higher values than experimental values, while others exhibit lower values. Higher values were obtained by Cox, Halpin Tsai, Hirsch and Nielson models compared to experimental values. On the other hand, lower results were obtained in the more conservative models which take into account the random distribution of the fibers.For example, in the Tsai-Pagano model, the $\eta$ coefficient is calculated to be the applied longitudinal direction (longitidiual) and transverse to the load.

From Equation 25, it can be seen that the Erandom value is more dependent on the modulus of elasticity ( $\left.E_{\text {transverse }}\right)$ perpendicular to the load than the modulus of elasticity ( $E_{\text {longitudinal }}$ in the load direction.This model seems to be a more conservative model than the other models.The modulus of elasticity found using the Tsai-Pagano model is lower than that of the experimental data. Another example that supports this idea is that a higher value of 0.6 , rather than 0.2 , of the $\eta$ coefficient recommended for random fiber-reinforced composites in the MRoM model results in closer results to the experimental data.This result reveals and supports that fiber orientation in our composite material is generally parallel to the tensile load.

$$
E_{\text {random }}=\frac{3}{8} E_{\text {longitudinal }}+\frac{5}{8} E_{\text {transverse }}
$$

As a natural consequence of the extrusion process, cotton fibers are often oriented in the extrusion direction, as seen in Figure 4. It is obvious that models which are considered less effective in the transverse direction than the direction of extrusion are more likely to presents closest results on such composite materials obtained by the extrusion method.

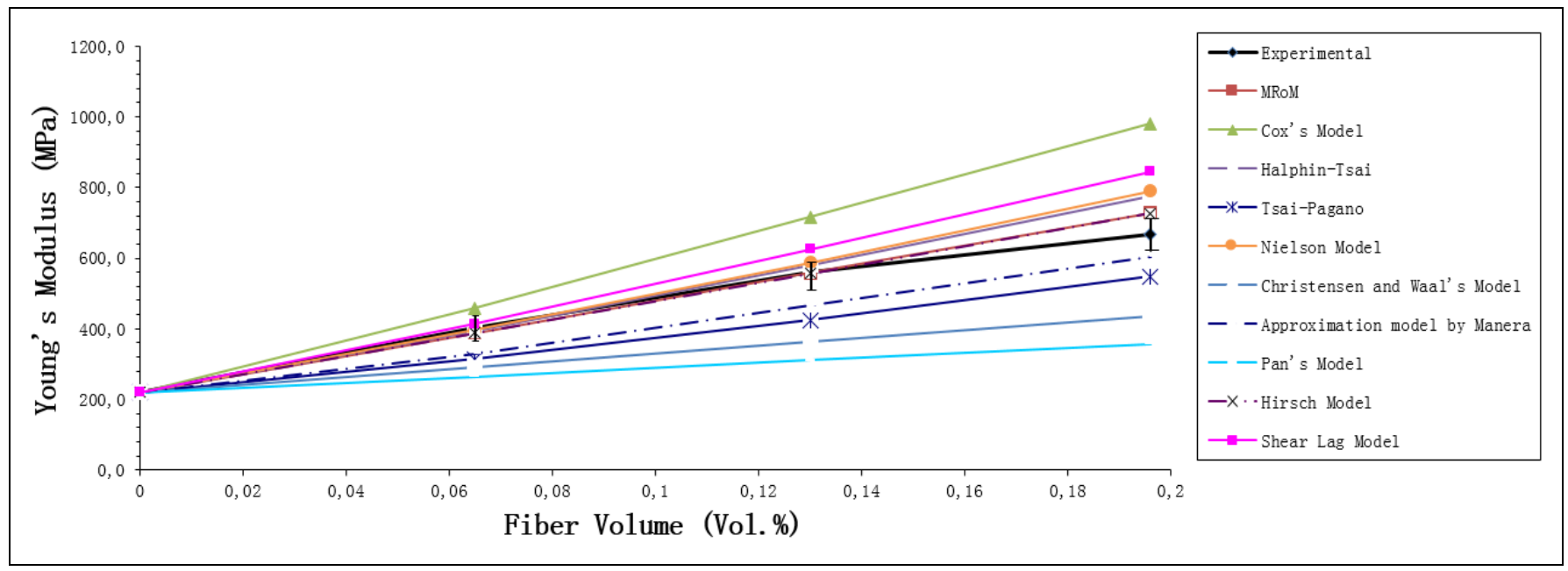

Figure 4: Young's modulus with respect to fiber content obtained by analytical models. 


\subsection{Results to be generally outlined}

1 As the fiber ratio increases, the value differences between the experimental and analytical models are also increasing. The reason for this is that as the fiber ratio increases, void formation in the composite structure also increases. Therefore, the composite structure can be moved away from the ideal structure assumed in the models,

2 Among the analytical models that can be used in the elastic modulus estimations of composite materials, it is understood that the models which consider the effect of the fiber orientation effect least will be more valid. As a result, the extrusion process usually results in the orientation of the cotton fibers in the extrusion direction as it is presented in Figure 5 which is obtained by optical inspections.

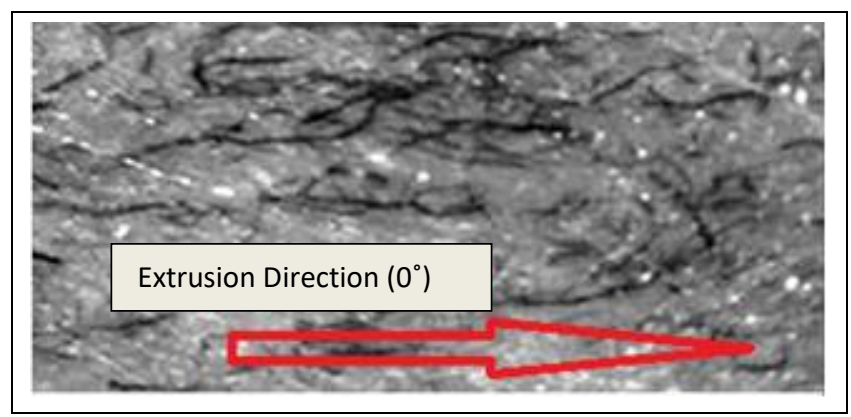

Figure 5: Fiber orientation in composite structure.

Another method used to predict the mechanical properties of composite materials is the "Finite Elements" (FEA) analysis.

Figure 6 shows the results of the tensile test results used in the FEA of the matrix element and cotton fibers. Tensile testing of cotton fibers were performed due to EN ISO 2062. In FEA, a representative volume element is used which usually represent the whole structure.The modeling of composite materials with cotton fiber content of $6.5 \%, 13 \%$ and $19.6 \%$, in the modeling step with the "Finishing Elements Method" which was carried out in the computer media by taking advantage of optical and Scanning Electron Microscope (SEM) images.

Computer-aided designs (CAD modeling) of composite materials were carried out through Solidworks and ANSYS Mechanical APDL version, and analyzes were performed with ANSYS Workbench version.

The most critical points in modeling behavior of composite materials by the finite element method are;

1. To construct the unit cell that will be analyzed and represent the entire composite structure as close as to reality,

2. Proper assignment of fiber and matrix material behavior in the analysis program,

3. To determine the boundary conditions correctly during the analysis step.

In addition to these points, some additional points such as meshing, element selection, correct identification of the fiber matrix interface state can also affect the results.We can list the following steps in modeling and analyzing composites in the finite element method.

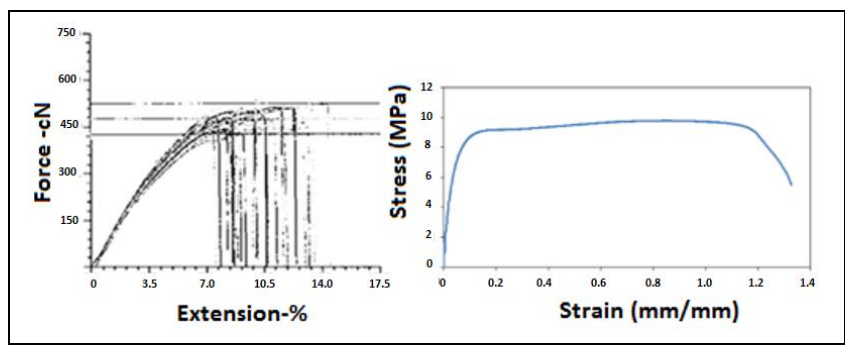

Figure 6: Tensile test curves for fiber (Left) and matrix element (Right).

- CAD step:In order to predict the mechanical properties of composites by FEA, it is critical to form solid models as close as possible to the real composite structure. Fiber distributions of such composites have a significant effect on mechanical properties. For this purpose, an exemplary area shown in Figure 7 was selected in the modeling of composites having arbitrary fiber distribution in the CAD step.Based on the orientation of the fibers in the selected area, the CAD model of composite construction was created with the help of the Solidworks software,

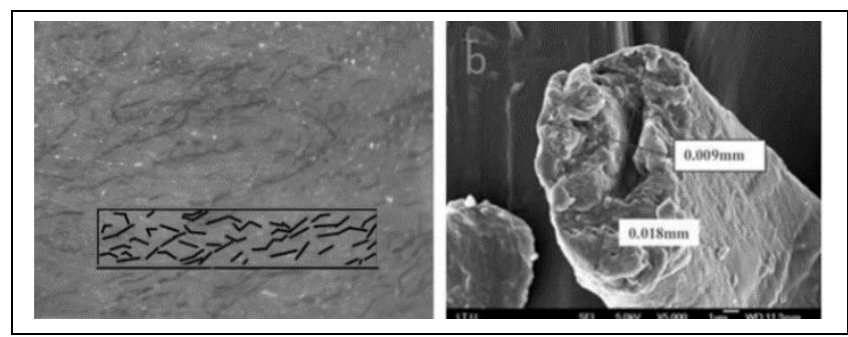

Figure 7: Exemplary area in composite structure (Left) and fiber properties (Right).

- Transferring CAD model to ANSYS and creating volumes: At this stage of the modeling, the volumes of the fiber and matrix elements forming the composite structure were created. The aim of this work is to create fiber voids in the matrix phase, taking fibers into account.The "Classic" version of the "ANSYS" program is used to create the matrix structure during the CAD model. Fiber volumes are extracted from matrix by using "Overlap" command in the software. Thus, the fiber and matrix phases did not overlap in the CAD model and formed different volumes,

- Modeling the final form of the composite structure by combining the matrix phase and cotton fiber: Matrix volume created in ANSYS program and the fibers are combined in Solidworks program in order to create final composite structure. The CAD modeling completed composite structure with. STEP extension has been transferred to the ANSYS Workbench version for analysis,

- Identification of the matrix and fiber elements of the composite structure:To define the matrix and fiber element transferred to the ANSYS Workbench program as close to the experimental data as possible, is a critical step in modeling the behavior of the entire composite structure. In this study, the matrix and reinforcement element are defined in the analysis program by deriving from the experimental data of 
tensile test of matrix material and cotton fiber. The interfacial bonding between fiber and matrix in model was considered as bonded,

- Meshing:Meshing is known as a factor that has an effect on the finite element analysis results.In meshing step, the composite structure is divided into various elements which has known behaviors for physical effects. As a result of the meshing step, the entire composite structure becomes a mesh-net structure consisting of elements connected by common end points (Figure 8).

\subsection{The critical points in Meshing step}

1. The end points of the fiber and matrix elements must be united.

2. The "Mesh" should be applied on fibers more precisely than the matrix material.

3. For this study, $0.2 \mathrm{~mm}$ mesh element size for the matrix, $0.1 \mathrm{~mm}$ for the fibers is suitable.

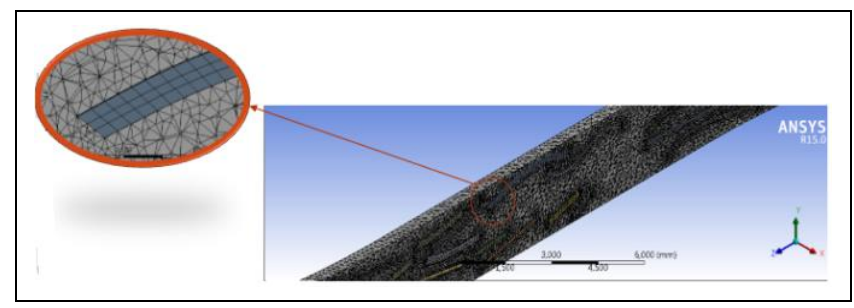

Figure 8: Meshing for fiber and matrix element.

- Identification of boundary conditions:Boundary conditions must be specified in order to apply the tensile test conditions during the analysis step. For this step, one surface of the composite sample is held constant during application of the load, while a tensile load is applied to the other surface. The tensile load is gradually increased as in the tensile test. The boundary conditions are presented in Figure 9. Load was applied to model step by step,

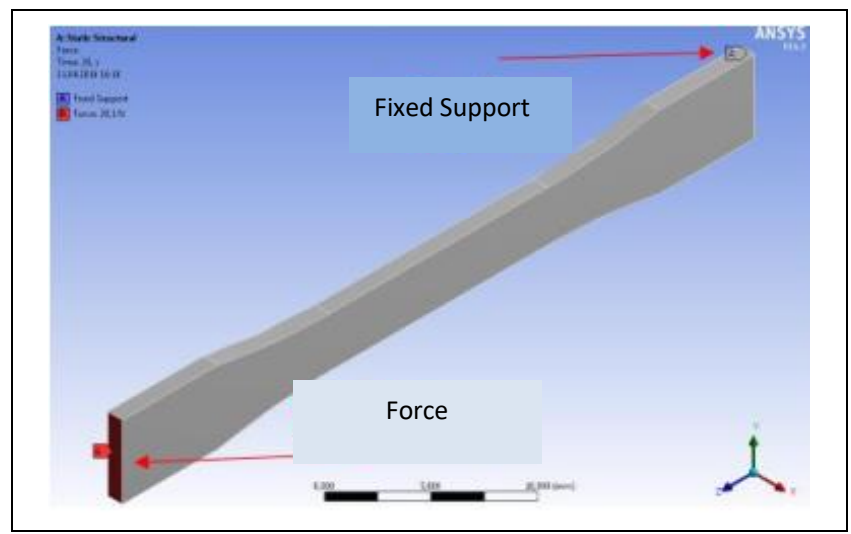

Figure 9: Boundary conditions.

Figure 10 shows the stress-strain curves for the experimental and finite element analysis of a composite material containing $13 \%$ cotton fiber by volume. The stress and strain values were obtained by taking results from each loading steps. As the obtained results were examined, the elastic modulus value of the composite material was measured experimentally as $560 \mathrm{MPa}$, while the value of the elastic material modulus of the composite material was obtained approximately 657 Mpa by FEA. A difference of about $17 \%$ between the two values was observed. It is also observed that the behavior of the composite material under tensile load is modeled successfully by the finite element method in the low deformations while the difference between the results obtained by the experimental and finite element methods increased by the high deformations.

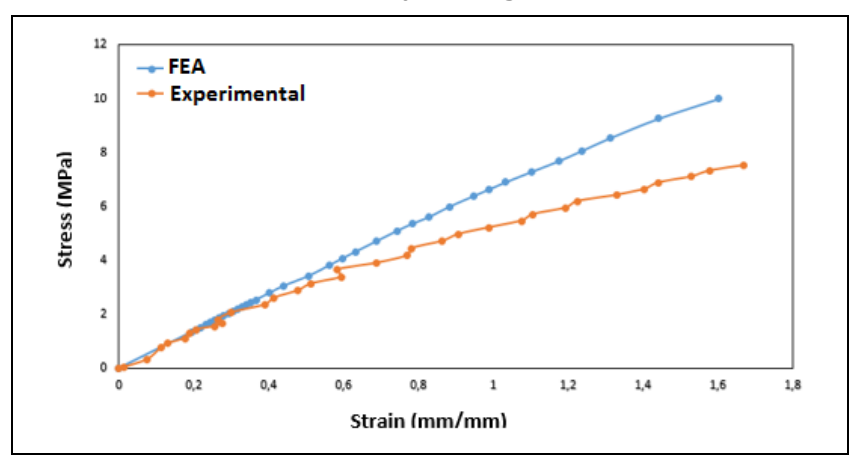

Figure 10: Elastic regions of composite materials obtained by experimantal and FEA.

Table 2 shows the young's modulus obtained by experimental and finite element methods with respect to different volumetric fiber ratios. From the results, it can be seen that the difference between the values of modulus of elasticity changes between $17 \%$ and $23 \%$.

Table 2: Young's Modulus due to volumetric ratio.

\begin{tabular}{cccc}
\hline Method & $\mathrm{E}_{6,5}(\mathrm{MPa})$ & $\mathrm{E}_{13}(\mathrm{MPa})$ & $\mathrm{E}_{19,6}(\mathrm{MPa})$ \\
\hline $\begin{array}{c}\text { Experimental } \\
\text { FEA }\end{array}$ & 403 & 560 & 667 \\
\hline
\end{tabular}

Figure 11 shows the stress (vonMises) distribution of the composite structure after finite element analysis. Analysis of the finite elements revealed that the highest tensile values were observed at the fiber matrix interface. We can therefore expect damage to begin to occur in these regions. Another consequence is that the critical importance of the fiber matrix interface state strength values is further supported by FEA.

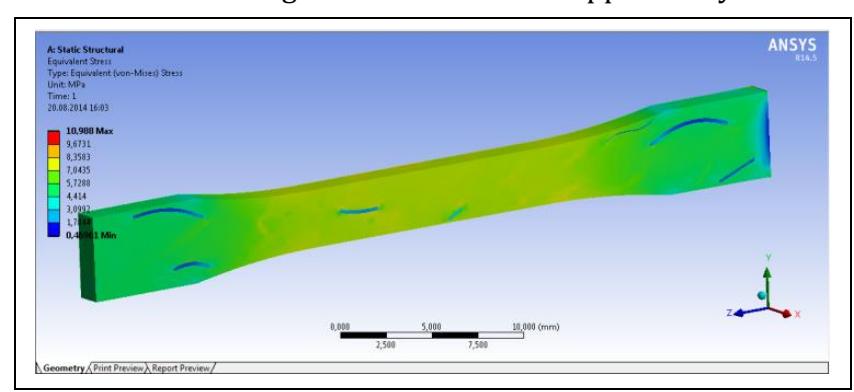

Figure 11: Stress distribution in fiber / matrix interfacial region after FEA.

Some defects that can occur in the composite structure in order to support the differences between the finite element and the experimental results are given in Figure 11. Although fiber and matrix interface state of the composite structure is improved to an ideal level with the addition of 5\% maleic anhydride low fiber and matrix adhesion states can be observed at certain levels as shown in Figure 12 which is obtained from the T-FRP $/ 13 \%$ composite test sample. On the other hand as a natural consequence of the extrusion process air gaps in the composite structures can be observed locally. Such factors are 
factors that directly affect the modulus of elasticity of the composite material and may cause the experimental results to remain lower. Therefore the higher data obtained with the finite element method can be explained by considering such factors.

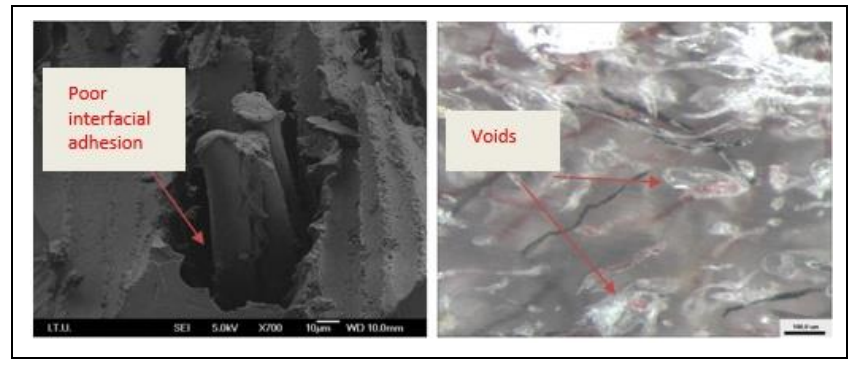

Figure 12: Defects in composite structure.

\section{Results}

The applicability of the finite element method and analytical models to estimate the elastic modulus values of randomly oriented natural fiber reinforced composites was studied.Among the analytical models for short fiber reinforced composites. Halphin-Tsai, Nielson, Hirsch and Shear Lag models are the models that give the closest results to the experimental data. In addition the difference between analytical and experimental results is found to be increased as the fiber ratio increases. On the other hand, among the analytical models that can be used in the elastic modulus estimations of composite materials. It is understood that models that take into account the fiber orientation effect least are more valid. A difference of about $17-23 \%$ was found between the experimental results and the results obtained by the finite element method. The reason for this difference is thought to be the formation of a void structure as a natural consequence of composite production.It is important that this work provides pioneering results for the possible future works on the analytical and finite element methods used to model elastic regions of such composites in relation to tensile load.

\section{References}

[1] Whitcomb JD. "Three-dimensional stress analysis of plain weave composites". Composite Materials: Fatigue and Stresses, 3, 16-39,1990.

[2] Guedes JM, Kikuchi N. "Preprocessing and post processing for materials based on the homogenization method with adaptive finite element methods". Computer Method in Applied Mechanics and Engineering, 83(2), 143-198, 1990.

[3] Chapman C, Whitcomb J. "Effect of assumed tow architecture on predicted moduli and stresses in plain weave composites". Journal of Composite Materials, 29(16), 2134-2159, 1995.

[4] Ng SP, Tse PC, Lau KJ. "Numerical and experimental determination of in plane elastic properties of $2 / 2$ twill weave fabric composites". Composites Part B, 29B, 735-744, 1998

[5] Dasgupta A, Agarwal RK, Bhandarkar SM. "Threedimensional modelling of woven-fabric composites for effective thermo mechanical and thermal properties". Composites Science and Technology, 56, 209-223,1996.

[6] Karkkainen RL, Sankar BV. "A direct micromechanics method for analysis of failure initiation of plain weave textile composites". Composite Science and Technology, 66, 137-150, 2006.
[7] Kim HJ, Swan CC. "Voxel-based meshing and unit-cell analysis of textile composites". International Journal for Numerical Methods in Engineering, 56, 977-1006, 2003.

[8] Lomov SV, Belov EB, Bischoff T. "Carbon composites based on multiaxial multiply stitched preforms. Part I-Geometry of the preform". Composites Part A, 33, 1171-1183, 2002.

[9] Takano N, Uetsuji Y,Kashiwagi Y, Zako M. "Hierarchical modelling of textile composite materials and structures by the homogenization method". Modelling and Simulation in Materials Science and Engineering, 7, 207-231,1999.

[10] Lomov SV, Ivanov DS, Verpoest I, Zako M. "Meso-FEModelling of Textile Composites: Road map. data flow and algorithms". Composites Science and Technology, 67, 1870-1891, 2007.

[11] Sih GC, Carpinteri A, Surace G. Advanced Technology For Design and Fabrication of Composite Materials and Structures. $1^{\text {st }}$ ed. Dordrecht, Netherlands, Kluwer Academic Publishers, 1995.

[12] Cox HL. "The elasticity and strength of paper and other fibrous materials". British Journal of Applied Physics, 3, 72-79, 1952.

[13] Halpin JC. "Stiffness and expansion estimates. for oriented short fiber composites". Journal of Composite Materials, 3, 720-724, 1969.

[14] Halpin JC, Pagano NJ. "The laminate approximation for randomly oriented fibrous composites". Journal of Composite Materials, 3, 720-724,1969.

[15] Nielson LE. Mechanical Properties of Polymer and Composites. 1 ed. New York, USA, Marcel Dekker, 1974.

[16] Christensen RM, Waals FM. "effective stiffness of randomly oriented fiber composites". Journal of Composite Materials, 6, 518-532, 1972.

[17] Lee LH. "Strength-composition relationships of random short glassfiber-thermoplastics composites". Polymer Engineering and Science, 9, 213-219,1969.

[18] Manera M. "Elastic properties of randomly oriented short fiberglass composites". Journal of Composite Materials, 11, 235-247,1977.

[19] Pan N. "The elastic constants of randomly oriented fiber composite: A new approach to prediction". Science and Engineering of composite materials, 5, 63-72, 1996.

[20] Hirsch T]. "Modulus of elasticity of concrete affected by elastic moduli of cement paste matrix and aggregate". Journal of American Concrete Institute, 59, 427-451, 1962.

[21] Brody H, Ward IM. "Modulus of short carbon and glass fiber reinforced composites". Polymer Engineering Science, 11, 139-151,1971.

[22] Chou TW, Nomura S. "Fiber orientation effects of the thermoplasticproperties of short fiber composites". Fibre Scienceand Technology, 14, 279-291,1981.

[23] Fu SY, Lauke B. "Strength anisotropy of misaligned shortfiberreinforced polymers". Composite Scienceand Technology, 59, 699-708, 1999.

[24] Hine PJ, Davidson N, Duckett RA, Ward IM. "Measuring thefiber orientation and modelling the elastic properties of injectionmoulded long-glass-fiberreinforced nylon". Composite Science and Technology, 53, 125-131, 1995.

[25] Ji-Zhao L. "Predictions of tensile strength of short inorganic fibrereinforced polymer composites". Polymer Testing, 30, 749-752,2011.

[26] Piggott MR. "Short fibre polymer composites: A fracturebased theoryof fibre reinforcement". Journal of Composite Materials, 28, 588-606,1994. 
[27] Epaarachchi J, Ku H, Gohel K. "Simplified empirical model forprediction of mechanical properties of random short fibre/vinylestercomposites". Journal of Composite Materials, 44(6), 779-788, 2010.

[28] Biagiotti J, Fiori S, Torre L, Lopez-Manchado MA, Kenny JM. "Mechanical properties of polypropylene matrix compositesreinforced with natural fibres: A statistical approach". PolymerComposites, 25(1), 26-36,2004.

[29] Angelo GF, Mark TK, Ning Y. "Predicting the elastic modulus ofnatural fibre reinforced thermoplastics". Composites: Part A, 37, 1660-1671, 2006.

[30] Zeronian SH. "The mechanical properties of cotton fibers". Journal of Applied Polymer Science, 47, 445-461, 1991.

[31] Mazumdar SK. Composites Manufacturing Materials, Product and Process Engineering. $1^{\text {st }}$ ed. United States, CRC Press, 2002.

[32] Bakkal M, Bodur MS, Berkalp OB, Yilmaz S. "The effect of reprocessing on the mechanical properties of the waste fabric reinforced composites". Journal of Materials Processing Technology, 212, 2541-2548, 2012.

[33] Zárate CN, Aranguen MI, Reboredo MM. "Resol-vegetable fibers composites". Journal of Applied Polymer Science, 77, 1832-1840, 2000.

[34] Halpin JC. "Stiffness and expansion estimates, for oriented short fiber composites". Journal of Composite Materials, 3 , 720-724, 1969 .
[35] Halpin JC, Pagano NJ. "The laminate approximation for randomly oriented fibrous composites". Journal Compos Mater, 3, 720-724, 1969.

[36] Nielson LE, Landel RF. Mechanical properties of polymer and composites. $2^{\text {nd }}$ ed. NewYork: Marcel Dekker, 1974.

[37] Christensen RM, Waals FM. "Effective stiffness of randomly oriented fiber composites". Journal of Composite Materials, 6, 518-532, 1972.

[38] Lee LH. "Strength-Composition relationships of random short glassfiber-thermoplastics composites". Polymer Engineering and Science, 9, 213-219, 1969.

[39] Tsai SW, Pagano NJ. Composite Materials Workshop. 1 ed. Stamford, USA, Technomic Publishing Co., 1968.

[40] Manera M. "Elastic properties of randomly oriented short fiber-glass composites". Journal of Composite Materials, 11, 235-247, 1977.

[41] Pan N. "The elastic constants of randomly oriented fiber composite: A new approach to prediction". Science and Engineering of composite materials, 5(962), 63-72, 1996.

[42] Tucker CL, Liang E. "Stiffness prediction for unidirectional short-fiber composites: Review and evaluation". Composites Science and Technology, 59, 655-671, 1999. 